\title{
STUDI MODEL ALIRAN FLUIDA DAN PERPINDAHAN PANAS PADA PBMR.
}

\author{
Achmad Fatich Al-Qodri ${ }^{1)}$, Sudarmono ${ }^{2)}$ \\ ${ }^{1)}$ UIN Maulana Malik Ibrahim Malang; ${ }^{2)}$ PTRKN-BATAN-Serpong \\ e-mail: smonomono2003@yahoo.com
}

\begin{abstract}
Abstrak
Reaktor tipe Pebble bed merupakan opsi yang menjanjikan untuk teknologi reaktor generasi mendatang dan memiliki potensi untuk memberikan pembangkitan listrik dengan efisiensi tinggi dan murah.Perpindahan panas reaktor ini menghadapi kendala akibat kompleksitas yang berkaitan dengan desain aliran panas.Dengan demikian, untuk mensimulasikan secara baik aliran dan perpindahan panas reaktor modular pebble bed ini memerlukan suatu model perpindahan panas yang berhubungan dengan radiasi serta konveksi dan konduksi panas.Dalam studi ini, suatu model dengan kemampuan untuk mensimulasikan aliran fluida dan perpindahan panas dalam teras reaktor modular pebble bed telah dikembangkan.Model ini diterapkan pada suatu personal computer (PC) yang menggunakan program komputer Matlab r2008a Versi 7.1.Beberapa parameter penting aliran fluida dan perpindahan panas telah dipelajari, termasuk penurunan tekanan (pressure drop) di teras reaktor, koefisien perpindahan panas, bilangan Nusselt, dan konduktivitas panas efektif pebble bahan bakar. Hasil yang diperoleh dari percobaan simulasi menunjukkan adanya suatu tekanan yang merata pada arah radial untuk suatu rasio diameter teras terhadap elemen bakar $(D / d)>20$ dan koefisien perpindahan panas meningkat seiring dengan peningkatan temperatur dan laju alir massa pendingin. Model ini dapat menjelaskan secara memadai fenomena aliran panas dan perpindahan panas dan kehilangan tekanan melalui friksi dalam PBMR tipe pebble bed.
\end{abstract}

Kata kunci: Aliran fluida, perpindahan panas, PBMR, packed bed, penurunan tekanan

\begin{abstract}
The pebble bed type high temperature gas cooled nuclear reactor is a promising option for next generation reactor technology and has the potential to provide high efficiency and cost effective electricity generation. The reactor unit heat transfer poses a challenge due to the complexity associated with the thermalflow design. Therefore to reliably simulate the flow and heat transport of the pebble bed modular reactor necessitates a heat transfer model that deals with radiation as well as thermal convection and conduction. In this study, a model with the capability to simulate fluid flow and heat transfer in the pebble bed modular reactor core has been developed. The developed model was implemented on a personal computer using Matlab r2008a Version 7.1 programming language. Several important fluid flow and heat transfer parameters have been examined: including the pressure drop over the reactor core, the heat transfer coefficient, the Nusselt number and the effective thermal conductivity of the fuel pebbles. Results obtained from the simulation experiments show a uniform pressure in the radial direction for a core to fuel element diameter $(D / d)$ ratio $>20$ and the heat transfer coefficient increases with increasing temperature and coolant mass flow rate. The model can adequately account for the flow and heat transfer phenomenon and the loss of pressure through friction in the pebble bed type high temperature nuclear reactor.
\end{abstract}

Key words:Fluid flow, heat transfer, PBMR, packed bed, pressure drop 


\section{PENDAHULUAN}

Simulasi aliran dan perpindahan panas yang baik merupakan dasar analisis PLTN karena reaktor nuklir pada dasarnya mampu menghasilkan semua daya yang diinginkan selama ia dapat dipindahkan dari teras. Dengan demikian, suatu analisis yang lengkap terhadap kesetimbangan energi reaktor menjadi suatu keharusan ${ }^{[1]}$. Pebble BedModular Reactor (PBMR) merupakan salah satu proyek reaktor Gen IV yang harus memenuhi kriteria Gen IV ${ }^{[1]}$, yaitu: kesinambungan, ekonomi dan ketahananproliferasi serta keselamatan dan kehandalan.

Kemampuan pengambilan panas yang dihasilkan dari teras (baik pada operasi normal maupun kondisi pengecualian) merupakan suatu titik kunci dari kriteria keempat.Reaktor pebblebeddapat dipandang sebagai suatu fixed atau packed bed reactor $^{[2]}$. Desain packed bed reactor didasarkan pada: mekanisme transfer panas dan massa, penurunan aliran dan tekanan fluida melalui bed padatan.Transfer panas unit reaktorpebble bedmenghadapi permasalahan yaitu bahwa ia meliputi suatu geometri tiga dimensi yang kompleks dan tersusun dari beragam material. Hal ini memerlukan suatu model transfer panas yang berkaitan dengan radiasi, konveksi, dan konduksi menggunakan berbagai teknik analisis dan perangkat simulasi.

E. Achenbach ${ }^{[3]}$ mempelajari karakteristika panas dan aliran dari packed bed dan menyarankan persamaan untuk prediksi transfer panas konveksi, penurunan tekanan (pressure drop), konduktivitas termal efektif dan transfer panas dinding.

Tujuan studi ini adalah untuk mempelajari pengembangan suatu model dengan kemampuan untuk mensimulasikan aliran dan transfer panas pada PBMR menggunakan program komputer Matlab r2008a Versi 7.1.Model ini mencermati aliran laminar dan turbulendi tepi bahan bakar pebble spheris tunggal dan parameter transfer panas, termasuk penurunan tekanan di teras reaktor, koefisien transfer panas, bilangan Nusselt, dan konduktivitas termal efektif dari bahan bakar pebble.

\section{TEORI}

\section{Program MATLAB}

Program MATLAB (MATrix

LABoratory)adalah suatu program untuk analisis dan komputasi numerik. Program ini merupakan suatu bahasa pemrograman matematika lanjutan yang dibentuk dengan dasar pemikiran menggunakan sifat dan bentuk matriks. MATLAB merupakan merk software yang dikembangkan oleh Mathworks.Inc. merupakan software untuk perhitungan numerikpemrograman tingkat tinggi berbasis matriks. Program ini digunakan untuk menyelesaikan masalahmasalah yang melibatkan operasi matematika elemen, matrik, optimasi, aproksimasi dll. Sehingga Matlab banyak digunakan untuk: matematika dan komputasi; pengembangan dan algoritma; pemrograman pemodelan, simulasi dan pembuatan prototipe; analisis data, eksplorasi dan visualisasi; analisis numerik dan statistik; serta pengembangan aplikasi teknik.

\section{Reaktor Pebble Bed Modular (PBMR=Pebble bedModular Reactor)}

Desain PBMR didasarkan pada teknologi HTGR (High Temperature Gascooled Reactor), yang pada awalnya dikembangkan di Jerman ${ }^{[4]}$ seperti ditunjukkan pada pada Gambar 1. PBMR merupakan reaktor bermoderasi grafit, berpendingin helium yang menggunakan siklus gas langsung atau tak-langsung untuk mengubah panas yang dibangkitkan oleh fisi nuklir menjadi energi listrik dengan bantuan siklus Brayton helium.

PBMR dipandang memiliki keselamatan melekat akibat fitur material yang digunakan, pengungkungan bahan bakar dalam lapisan ganda, inertia panas moderator grafit, efisiensi termal tinggi, serta siklus bahan bakar yang fleksibel dengan kemampuan untuk mencapai tingkat derajat bakar (burn-up) tinggi.Desain bahan bakar bersama dengan penggunaan fluida pendingin helium dan struktur teras yang non-metal memungkinkan temperatur operasi yang tinggi. 


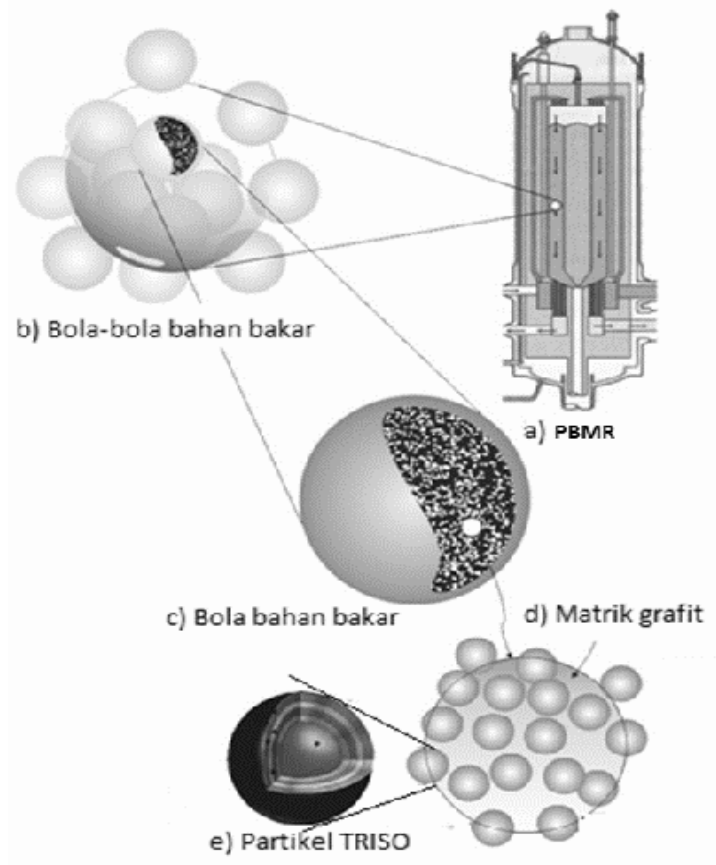

Gambar 1. Desain PBMR

Bahan bakar PBMR didasarkan pada desain bahan bakar Jerman yang berkualitas tinggi yang terdiri atas partikel Low Enriched Uranium-TripleCoated Isotropic (LEU-TRISO) yang terkandung dalam suatu bola grafit. Partikel-partikel berlapis ini terdiri atas suatu kernel uranium dioksida yang diselubungi oleh empat pelapisan untuk membentuk bola bahan bakar atau pebble dengan diameter $6 \mathrm{~cm}$.Model dan dimensi keempat pelapisan TRISOtersebut adalah penyangga karbon berpori (porous carbon buffer,C), piro karbon bagian dalam (inner pyrolytic carbon, IPyC), silikon karbon (SiC), dan piro karbon bagian luar (outer pyrolytic carbon, OpyC), seperti di tunjukkan pada Gambar 2.

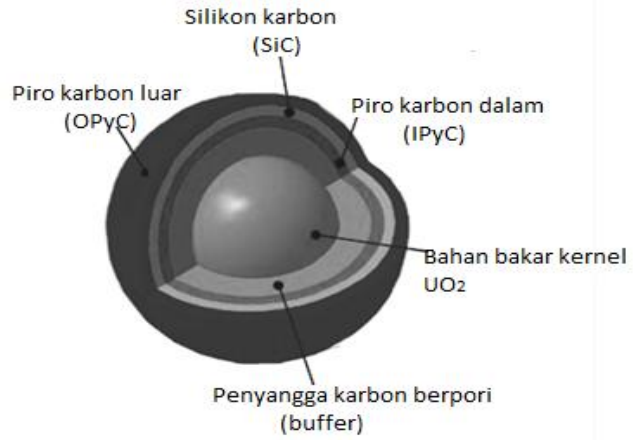

Gambar 2. Partikel TRISO, dengan jejari :

$\mathrm{r}_{\text {kernel }}=250 \mu \mathrm{m}, \mathrm{r}_{\mathrm{OPyC}}=460 \mu \mathrm{m}, \mathrm{r}_{\mathrm{IPyC}}=385$ $\mu \mathrm{m}$ dan $r_{\text {buffer }}=345 \mu \mathrm{m}$
Detil aliran dan transfer panas teras pada PBMR ditunjukkan pada Gambar 3. Untuk memindahkan panas yang dihasilkan oleh reaksi fisi nuklir, pendingin helium memasuki teras reaktor dari bagian atas dan mengalir ke bawah melalui rongga antar bola-bola bahan bakar, kemudian meninggalkan teras pada bagian bawah setelah dipanaskan sampai ke temperatur yang lebih tinggi. Pada PBMR, keseluruhan transfer panas terdiri atas:

- Transfer panas konduksi pada arah radial dan aksial (pebble-pebble, pebble-reflektor, semua padatan)

- Transfer panas konveksi antara partikel-partikel bed dan pendingin helium yang mengalir.

- Transfer panas radiasi (pebble-pebble, pebble-dinding reflektor, barel terasdinding bejana reaktor).

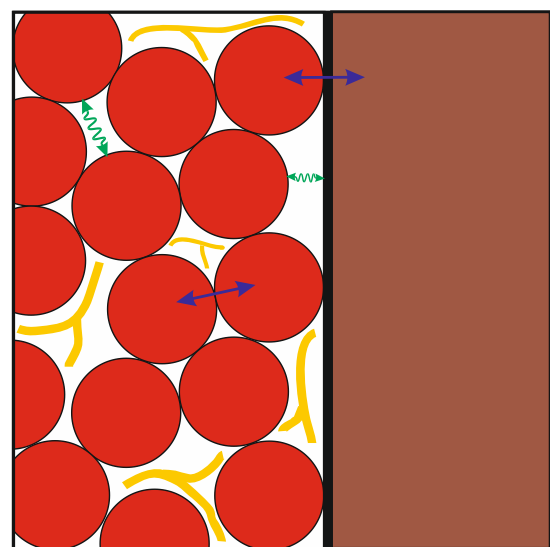

Gambar 3. Detil Transfer Panas

\section{Simulasi Aliran dan Transfer Panas PBMR}

Untuk PBMR, pendingin mengalir ke bawah melalui celah atau rongga yang ada di antara bola-bola bahan bakar yang panas. Dengan demikian, model fisis yang sesuai yang dirancang untuk sistem seperti ini digunakan di semua penelitian literatur ilmiah yang ada.Khususnya, model-model yang sesuai untuk mengevaluasi penurunan tekanan helium di teras dan transfer panas antara pebble bahan bakar dan pendingin helium serta konduktivitas termal efektif dari pebble bahan bakar diteliti. 


\section{Penurunan Tekanan pada pebble bed}

Penurunan tekanan di pebble bed akibat friksi merupakan suatu fenomena penting yang sangat mempengaruhi efektivitas transfer panas. Pentingnya penurunan tekanan adalah sedemikian sehingga ia memungkinkan penentuan ukuran yang sesuai dari mesin-turbo dan juga menentukan distribusi aliran melalui struktur teras yang terdiri atas blok grafit ${ }^{[5]}$. Walaupun kebocoran atau aliran bypass melalui struktur teras diminimalkan melalui desain, penurunan tekanan yang besar di pebble bedakan menyebabkan kebocoran atau aliran bypass terjadi. Untuk memodelkan dan mengevaluasi penurunan tekanan pada pebble bed akibat friksi, digunakan korelasi berikut ${ }^{[6]}$ :

$$
\Delta P=\psi \frac{H}{d} \frac{1-\varepsilon}{\varepsilon^{3}} \frac{1}{2 \rho}\left(\frac{\dot{m}}{A}\right)^{2}
$$

Dimana $\Delta \mathrm{P}$ adalah penurunan tekanan $(\mathrm{kg} . \mathrm{m}$ $\left.{ }^{1} \mathrm{~s}^{-2}\right), \rho$ adalah densitas fluida $\left(\mathrm{kg} . \mathrm{m}^{-3}\right), \quad \varepsilon$ adalah porositas bed, $\mathrm{d}$ adalah diameter pebble bahan bakar(m), A adalah luas tampang lintang $\left(\mathrm{m}^{2}\right), \quad \mathrm{H}$ adalah tinggi teras $(\mathrm{m})$, dan $\mathrm{m}$ adalah laju alir massa fluida $\left(\mathrm{m}^{3} \mathrm{~s}^{-1}\right)$. Untuk aplikasi reaktor pebble bed, koefisien penurunan tekanan diperoleh dengan persamaan empiris berikut ${ }^{[6]}$ :

$$
\psi=\frac{320}{\frac{\operatorname{Re}}{1-\varepsilon}}+\frac{6}{\left(\frac{\operatorname{Re}}{1-\varepsilon}\right)^{0.1}}
$$

Bilangan Reynolds Re diturunkan dari persamaan berikut dalam viskositas dinamik $\eta\left(\mathrm{kg} \mathrm{m}^{-1} \mathrm{~s}^{-1}\right)$ gas:

$$
\operatorname{Re}=\frac{\dot{m} d}{\eta A}=\frac{\rho v A d}{\eta A}=\frac{\rho v d}{\eta}
$$

Dimana $v$ adalah kecepatan aliran $\left(\mathrm{m} \mathrm{s}^{-1}\right)$, dengan $10^{0}<\mathrm{Re} /(1-\varepsilon)<10^{5}$ dan $0.36<\varepsilon<$ 0.42 .

Dari hasil eksperimen Carman dan Barthels, porositas terkait yang diperlukan untuk sirkulasi penurunan tekanan diestimasi sebesar $^{[3,5]}:-+$

$$
\varepsilon_{t}=0.78\left(\frac{d}{D}\right)^{2}+0.375
$$

$$
\begin{gathered}
\varepsilon_{w}=63.6\left(\frac{D}{d}+15\right)^{-2}+0.43 \\
\varepsilon_{c}=\varepsilon_{w}-\frac{\varepsilon_{w}-\varepsilon_{t}}{\left(1-\frac{d}{D}\right)^{2}}
\end{gathered}
$$

Substitusi Persamaan (4), (5), dan (6) ke Persamaan (2) memungkinkan kita membandingkan penurunan tekanan pada berbagai daerah bed untuk rasio D/d yang berbeda.

\section{Hubungan Transfer Panas}

Untuk menguraikan secara benar transfer panas dalam pebble bed, dilakukan perhitungan transfer panas akibat konveksi paksa dan untuk transport panas akibat konduksi dan radiasi. Sedangkan untuk transfer panas akibat konveksi paksa, suatu hubungan antara bilangan Nusselt, bilangan Reynolds, bilangan Prandtl, dan porositas pebble bed harus ditentukan.Transfer panas Q (Joule)dari pebble bahan bakar ke fluida pendingin sebagai fungsi laju alir massa pendingin dan perbedaan temperatur dihitung dengan persamaan:

$$
Q=\alpha A_{p}\left(T_{p}-T_{g}\right)
$$

Dimana $\alpha$ adalah koefisien transfer panas konveksi(W.m $\left.{ }^{-2}{ }^{\circ} \mathrm{C}\right), \quad \mathrm{A}_{\mathrm{p}}$ adalah luas permukaan daerah pebble bahan bakar $\left(\mathrm{m}^{2}\right)$, $\mathrm{T}_{\mathrm{p}}$ dan $\mathrm{T}_{\mathrm{g}}$ masing-masing adalah temperatur permukaan pebble bahan bakar $\left({ }^{\circ} \mathrm{C}\right)$ dan temperatur fluida gas helium $\left({ }^{\circ} \mathrm{C}\right)$. Koefisien transfer panas konveksi diberikan oleh Persamaan:

$$
\alpha=\frac{N u \lambda_{g}}{d}
$$

Dimana $\mathrm{Nu}$ adalah bilangan Nusselt, $\lambda_{\mathrm{g}}$ adalah konduktivitas termal gas $\left(\mathrm{W} . \mathrm{m}^{-1} .{ }^{0} \mathrm{C}^{-}\right.$ ${ }^{1}$ )dan d adalah diameter pebble bahan bakar.

Untuk menentukan hubungan antara bilangan Nusselt, bilangan Reynolds, bilangan Prandtl, dan porositas pebble bed, Gnielinski mengevaluasi hasil percobaan dari sekitar 20 peneliti $^{[3,5]}$. Teori ini didasarkan pada asumsi bahwa transfer panas bola dalam suatu pebble bed dapat berkaitan dengan transfer panas dari sebuah bola tunggal dengan menggunakan suatu faktor 
penyesuaian, yaitu $\mathrm{f}_{\varepsilon}$, yang bergantung pada porositas pebble bed. Dari studi evaluasi dan asumsi, diperoleh hubungan berikut ${ }^{[5]}$ :

$$
N u=f_{\varepsilon} \times N u s
$$

Dimana

$$
f_{\varepsilon}=1+1.5(1-\varepsilon)
$$

Dan Nus, bilangan Nusselt dari sebelah bola tunggal dinyatakan dengan:

$$
N u s=2+\sqrt{N u_{l}^{2}+N u_{t}^{2}}
$$

Dengan bilangan Nusselt untuk aliran laminar diberikan oleh:

$$
N u_{l}=0.664\left(\frac{\mathrm{Re}}{\varepsilon}\right)^{1 / 2} \operatorname{Pr}^{1 / 3}
$$

Dan bilangan Nusselt untuk aliran turbulen diberikan oleh:

$$
N u_{t}=\frac{0.037\left(\frac{\mathrm{Re}}{\varepsilon}\right)^{0.8} \operatorname{Pr}}{1+2.443\left(\frac{\mathrm{Re}}{\varepsilon}\right)^{-0.1}\left(\mathrm{Pr}^{2} / 3-1\right)}
$$

Dimana Pr adalah bilangan Prandtl.

Persamaan (9) sampai (13) berlaku untuk $100<\operatorname{Re}<105, \quad \operatorname{Pr}>0.6 \quad$ dan $0.36<\varepsilon<0.42$. Bilangan Nuselt juga dapat ditentukan berdasarkan pada hubungan berikut $^{[6]}$ :

$$
\begin{aligned}
N u=1.27 \frac{\operatorname{Pr}^{1 / 3}}{\varepsilon^{1.18}} \operatorname{Re}^{0.36} \\
\quad+0.033 \frac{\operatorname{Pr}^{1 / 2}}{\varepsilon^{1.07}} \operatorname{Re}^{0.86}
\end{aligned}
$$

\section{Konduktivitas Termal Efektif}

Untuk menjelaskan semua mode transfer panas non-konveksi dalam struktur fase padat, konduktivitas termal efektif dievaluasi. Bentuk spesifik dari konduktivitas termal efektif yang diterapkan pada bagian homogen (yaitu, bagian di luar daerah dekat-dinding) dapat diuraikan berdasarkan pada korelasi Zehner-Bauer, Schlunder $(\mathrm{ZBS})^{[7]}$. Konduktivitas termal efektif pebble bed tidak hanya bergantung pada sifat material partikel, tetapi juga bergantung pada kondisi aliran dan transfer panas serta ukuran dan bentuk partikel ${ }^{[3]}$. Konduktivitas termal efektif dipandang memiliki tiga komponen, yaitu:
- Konduksi melalui fase padat dan radiasi antar pebble $\lambda_{\mathrm{e}}^{\mathrm{r}}\left(\mathrm{W} \cdot \mathrm{m}^{-1} \cdot{ }^{0} \mathrm{C}^{-1}\right)$.

- Konduksi melalui fase padat dan melintasi fase fluida stasioner yang mengisi ruang antar pebble $\lambda_{\mathrm{e}}^{\mathrm{g}}\left(\mathrm{W} \cdot \mathrm{m}^{-1} \cdot{ }^{0} \mathrm{C}^{-1}\right)$.

- Konduksi melalui fase padat dan melintasi intermuka kontak antar pebble $\lambda^{\mathrm{c}}\left(\mathrm{W} . \mathrm{m}^{-1}\right.$. $\left.{ }^{0} \mathrm{C}^{-1}\right)$

\section{Konduksi melalui Fase Padat dan Radiasi antar Pebble}

Model Zehner dan Schluender dengan modifikasinya dapat digunakan untuk mengevaluasi komponen konduktivitas termal efektif dengan memperhitungkan radiasi ruang (void) interstitial dan konduksi solid. Model ini dinyatakan sebagai ${ }^{[8]}$ :

$$
\begin{aligned}
\lambda_{e}^{r}=\{[1-(1 & \left.-\varepsilon)^{1 / 2}\right] \varepsilon+\frac{(1-\varepsilon)^{1 / 2}}{\frac{2}{\xi_{r}}-1} \\
& \times \frac{B+1}{B} \\
& \left.\times \frac{1}{1+\frac{1}{\left(\frac{2}{\xi_{r}}-1\right) \Lambda}}\right\} 4 \sigma T^{3} d
\end{aligned}
$$

Dimana $\lambda_{e}^{r}$ adalah konduktivitas termal efektif radiasi ruang/void(W. $\left.\mathrm{m}^{-1} \cdot{ }^{0} \mathrm{C}^{-1}\right), \xi_{\mathrm{r}}$ adalah emisivitas pebble, $\sigma$ adalah konstanta Stefan-Boltzmann $\left(J_{\text {Joule. }}{ }^{\circ} \mathrm{C}^{-1}\right), \quad \mathrm{T}$ adalah temperatur $\left({ }^{\circ} \mathrm{C}\right)$, B adalah faktor deformasi seperti dinyatakan dalam Persamaan (16) dan $\Lambda$ adalah bagian konduktivitas termal efektif $\left(\mathrm{m}^{-2} \mathrm{C}^{-3} \mathrm{~s}^{-1}\right)$ yang melukiskan transfer panas radiasi dan dinyatakan dalam Persamaan $(17)^{[9]}$ :

$$
\begin{gathered}
B=1.25\left(\frac{1-\varepsilon}{\varepsilon}\right)^{10 / 9} \\
\Lambda=\frac{\lambda_{f}}{4 \sigma T^{3} d}
\end{gathered}
$$

Dimana $\lambda_{\mathrm{f}}$ adalah konduktivitas termal partikel bahan bakar. 
Konduksi melalui Fase Padat dan Melintasi Fase Fluida Stasioner yang Mengisi Interstistial Void antara Pebble

Komponen konduktivitas termal efektif yang menerangkan konduksi termal melalui fase padat dan melintasi fase fluida stasioner yang mengisi interstitial void antar pebble dinyatakan oleh:

$$
\begin{aligned}
& \frac{\lambda_{e}^{g}}{\lambda_{g}} \\
& =1-\sqrt{1-\varepsilon} \\
& +\frac{2 \sqrt{1-\varepsilon}}{1-\lambda B}\left[\frac{(1-\lambda) B}{(1-\lambda B)^{2}} \operatorname{In}\left(\frac{1}{\lambda B}\right)-\frac{B+1}{2}\right. \\
& \left.-\frac{B-1}{1-\lambda B}\right]
\end{aligned}
$$

Dimana B adalah faktor deformasi seperti pada Persamaan (16), $\quad \lambda_{e}^{g}$ adalah konduktivitas gas plus konduktivitas termal efektif konduksi padatan $\left(\mathrm{W} \cdot \mathrm{m}^{-1} \cdot{ }^{0} \mathrm{C}^{-1}\right)$, dan $\lambda=\lambda_{\mathrm{g}} / \lambda_{\mathrm{f}}$ adalah rasio konduktivitas. Model ini didasarkan pada aliran panas satu dimensi untuk konduksi melalui packed bed dari partikel bundar seperti dinyatakan oleh Zehner dan Schluender ${ }^{[7]}$.

\section{Konduksi Padat - Konduksi Luas Kontak - Model Konduksi Padat}

Komponen akhir dari konduktivitas termal efektif yang menjelaskan konduksi melalui pebble dan melintasi kontak antar pebble diprediksidengan suatu model berikut $^{[7]}$ :

$$
\frac{\lambda_{e}^{c}}{\lambda_{f}}=\left[\frac{3\left(1-\mu_{p}^{2}\right)}{4 E_{S}} f R\right]^{1 / 3} \frac{1}{0.531 S}\left(\frac{N_{A}}{N_{L}}\right)
$$

Dimana $\lambda_{e}^{c}$ adalah kontak plus konduktivitas termal efektif konduksi padat $\left(\mathrm{W} \cdot \mathrm{m}^{-1} \cdot{ }^{0} \mathrm{C}^{-1}\right), \mu_{\mathrm{p}}$ adalah rasio Poisson, $\mathrm{E}_{\mathrm{s}}$ adalah modulus Young(G.Pa), $\mathrm{R}$ adalah radius bola, dan $\mathrm{S}$ adalah konstanta terkait pengaturan volume pebble, $\mathrm{f}$ adalah gaya yang dinyatakan oleh Persamaan (20):

$$
f=P_{S} \frac{S_{F}}{N_{A}}
$$

Dimana $\mathrm{P}_{\mathrm{s}}$ adalah tekanan eksternal sebagai hasil dari stackedpebble $\left(\mathrm{kg} . \mathrm{m}^{-1} . \mathrm{s}^{-2}\right), \mathrm{S}_{\mathrm{F}}$ adalah konstanta terkait dengan pengaturan volumetric pebble dan $\mathrm{N}_{\mathrm{A}}=1 / \mathrm{d} 2$ dan $\mathrm{N}_{\mathrm{L}}=$ $1 / \mathrm{d}$ masing-masing merupakan jumlah partikel persatuan luas dan panjang.Dengan demikian konduktivitas termal efektif total adalah jumlah semua tiga konduktivitas:

$$
\lambda_{e}^{t}=\lambda_{e}^{r}+\lambda_{e}^{g}+\lambda_{e}^{c}
$$

Pengaruh konveksi gas pada transfer panas tidak dimasukkan dalam Persamaan (21).

\section{Korelasi Sifat-sifat Material}

Sifat-sifat termal material PBMR sangat penting, sehingga memerlukan representasi yang memadai, sehingga standard kendali yang telah ditetapkan digunakan untuk menghitung sifat-sifat termal material PBMR. Konduktivitas termal pendingin helium dan pebble bahan bakar ditentukan menggunakan hubungan di bawah ini.

\section{Sifat-sifat Termal Helium}

Sifat-sifat material helium sebagai fungsi temperatur ${ }^{[6]}$ digunakan untuk menghitung sifat-sifat material densitas helium, viskositas dinamis, kapasitas panas spesifik, konduktivitas termal yang berada dalam kisaran:

$0.1 \mathrm{MPa} \leq \mathrm{P} \leq 10 \mathrm{MPa}$ dan $293 \mathrm{~K} \leq$ $\mathrm{T} \leq 1773 \mathrm{~K}$

Densitas helium $\rho\left(\mathrm{kg} . \mathrm{m}^{-3}\right)$ adalah:

$$
\rho=48.14 \frac{P}{T}\left(1+0.4446 \frac{P}{T^{1.2}}\right)^{-1}
$$

Viskositas dinamis $\eta\left(\mathrm{kg} . \mathrm{m}^{-1} . \mathrm{s}^{-1}\right)$ adalah:

$$
\eta=3.674 \times 10^{-7} T^{0.7}
$$

Konduktivitas panas $\lambda_{\mathrm{g}}\left(\mathrm{W} \cdot \mathrm{m}^{-1}{ }^{0} \mathrm{C}^{-1}\right)$ adalah:

$$
\begin{aligned}
\lambda_{g}=2.682 & \times 10^{-3}(1+1.123 \\
& \times 10^{-3} \\
& \times P) T^{0.71\left(1-2.0 \times 10^{-4} P\right)}
\end{aligned}
$$

Kapasitas panas spesifik tekanan tetap adalah:

$$
\mathrm{C}_{\mathrm{p}}=5195\left(\mathrm{~J} \cdot \mathrm{kg}^{-10} \mathrm{C}\right)
$$

Kapasitas panas spesifik volume tetap adalah:

$$
\mathrm{C}_{\mathrm{v}}=3117\left(\mathrm{~J} \cdot \mathrm{kg}^{-1 \mathrm{o}} \mathrm{C}\right)
$$


ISSN: 2087-9946

$\mathrm{f}$ adalah gaya $(\mathrm{kg})$, sedangkan $\mathrm{P}_{\mathrm{s}}$ adalah tekanan eksternal sebagai hasil dari stackedpebble.

\section{Konduktivitas Panas Pebble Bahan Bakar}

Konduktivitas panas pebble bahan

bakar $\lambda_{\mathrm{f}}\left(\mathrm{W} \cdot \mathrm{m}^{-1} \cdot{ }^{0} \mathrm{C}^{-1}\right)$ diturunkan dengan menggunakan persamaan empirik dari bahan bakar Jerman ${ }^{[10]}$ seperti berikut:

$\lambda_{f}$

$=1.2768$
$\times\left(\frac{0.06829-0.3906 \times 10^{-4} T}{\text { DOSIS }+0.1931 \times 10^{-4} T+0.105+1.228 \times 10^{-4} T+0.042}\right)$

Untuk $450 \leq T \leq 300^{\circ} \mathrm{C}$

DOSIS adalah dosis radiasi neutron cepat $\left(10^{21}\right),{ }^{[7,10]}$.

\section{METODOLOGI}

Langkah yang dilakukan dalam studi ini dapat dijelaskan sebagai berikut:

1. Menentukan koefisien tekanan sebagai fungsi bilangan Reynold. Dengan data yang telah diketahui dari hasil eksperimen dan juga hubunganhubungan dengan beberapa koefisien lainnya seperti densitas fluida dan porositas bed.

2. Menentukan penurunan tekanan pada berbagai bagian pebble beduntuk berbagai rasio $\mathrm{D} / \mathrm{d}$. Untuk pebble bed tipe reaktor temperatur tinggi, rasio diameter teras $\mathrm{D}(\mathrm{m})$ terhadap diameter elemenbakar d (m) adalah (D/d) sangat besar. Semakin tinggi rasio diameter teras terhadap diameter elemen bakar, akan semakin kuat pengaruhnya pada penurunan tekanan. Jadi, untuk meneliti pengaruh rasio $\mathrm{D} / \mathrm{d}$ pada penurunan tekanan, diasumsikan untuk estimasi kasar, bahwa bed dibagi menjadi daerah dekat-dinding (indeks w), daerah tengah (indeks c), dan daerah rata-rata (indeks t).

3. Menentukan bilangan Nusselt sebagai fungsi bilangan reynolds, untuk transfer panas konveksi partikel-ke-fluida di teras pebble bed dengan $\operatorname{Pr}=0.7, \varepsilon=$ 0.39 . dengan ditentukan beberapa koefisien dalam persamaan yang nilainya tetap disetiap keadaan.

4. Menentukan bilangan Nusselt sebagai fungsi bilangan Reynolds untuk transfer panas konveksi partikel-ke-fluida untuk teras pebble bed dengan pembagian tig estimasi kasar pada langkah sebelumnya, yaitu dengan membagi daerahnya menjadi daerah dekat-dinding (near- wall), daerah tengah (center), dan daerah rata-rata (average).

5. Menentukan koefisien transfer panas konveksi a untuk teras pebble bedsebagai fungsi bilangan Reynolds. Dengan beberapa variasi pada koefisien transfer panas konveksi a sehingga didapatkan hubungan antara koefisien transfer panas konveksi $(\alpha)$ dan bilangan Reynolds.

6. Menentukan konduktivitas termal efektif pebble beduntuk kondisi helium dengan membandingkan beberapa persamaan dasar pada konduktivitas termal efektif.

7. Menentukan simulasi hasil persamaan yang didapatkan dengan menggunakan program matlab r2008a versi 7.1 sebagai berikut:

(a) Menentukan nilai-nilai yang memenuhi syarat dalam persamaan sesuai dengan hasil secara eksperimen.

(b) Memasukkan logika-logika serta variabel yang sesuai dengan persamaan kedalam program matlab.

(c) Memasukkan nilai-nilai variabel kedalam bentuk matrix.

(d) Memproses program yang berisi persamaan dengan masukan berupa nilai variabel yang sudah ditentukan sebelumnya.

(e) Mendapatkan hasil berupa tabel data perhitungan

(f) Memplot hasil berupa data perhitungan kedalam grafik hasil

(g) Menganalisis hasil dari simulasi 


\section{HASIL DAN PEMBAHASAN Penurunan Tekanan}

Penurunan tekanan di pebble bed ditunjukkan pada Gambar 4. Peningkatan laju alir pendingin menurunkan friksi fluida antara permukaan pebble dan fluida (pendingin), yang ditimbulkan sebagai hasil viskositas fluida. Koefisien penurunan tekanan selanjutnya menurun sesuai dengan peningkatan laju alir pendingin seperti tampak pada Gambar 4.Penurunan tekanan yang dihasilkan oleh resistensi terhadap aliran pada pebble bed dapat berubah-ubah menurut perubahan laju alir pendingin karena semua parameter lainnya adalah tetap, baik menurut geometri reaktor atau pun pemilihan pendingin. Gambar 5 menunjukkan perbandingan penurunan tekanan versus rasio diameter teras terhadap diameter elemen bakar (D/d) pada berbagai daerah pebble bed.Untuk aliran yang berkembang penuh, tekanan pada arah radial akan merata dan hanya berubah pada arah aksial. Variasi dalam porositas pada arah radial dijelaskan oleh variasi terkait pada kecepatan aksial untuk menjaga tekanan yang merata pada arah radial.

Aliran pendingin menyebabkan penurunan tekanan yang seharusnya tidak terlalu tinggi karena penurunan tekanan yang tinggi di sepanjang bed memerlukan pemompaan daya yang tinggi ke pompa pendingin. Tingginya penurunan tekanan dapat disebabkan oleh efek aliran bypass.

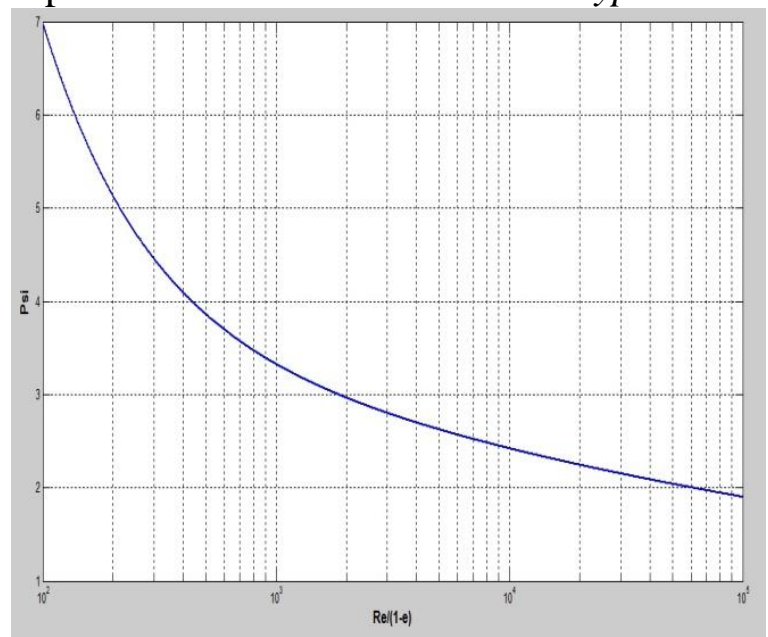

Gambar 4. Koefisien Penurunan Tekanan Pebble Bed

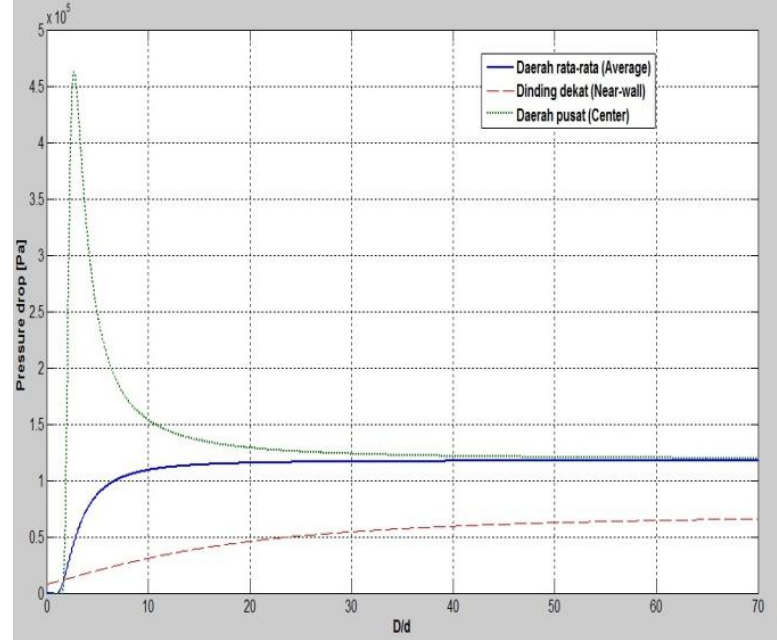

Gambar 5. Penurunan Tekanan pada

Berbagai Bagian Pebble Bed untuk Berbagai Rasio D/d

\section{Transfer Panas Konveksi}

Gambar 6 menunjukkan plot bilangan Nusselt sebagai suatu fungsi bilangan Reynolds untuk transfer panas konveksi partikel-ke-fluida untuk teras pebble bed.Bilangan Nusselt memberikan rasio transfer panas konveksi terhadap konduksi dan peningkatan transfer panas dari suatu permukaan yang terjadi dalam situasi riil dibandingkan pada transfer panas jika hanya konduksi yang terjadi. Mengacu pada Persamaan (7), transfer panas dipengaruhi oleh baik peningkatan koefisien transfer panas konveksi, luas permukaan terpanaskan, ataupun perbedaan temperatur di antara permukaan pebble dan bulk pendingin.

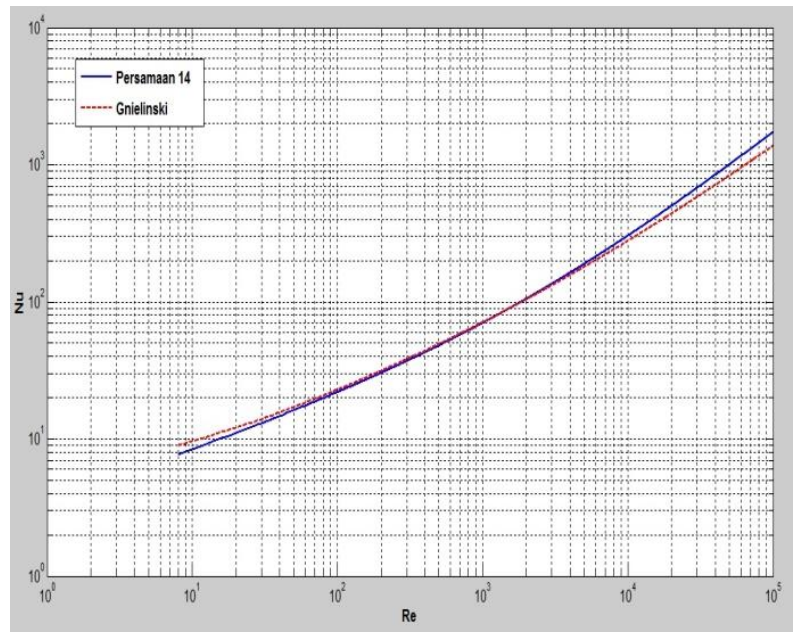

Gambar 6. Bilangan Nusselt sebagai Fungsi Bilangan Reynolds 
Keterangan : untuk Transfer Panas Konveksi Partikel-ke-Fluida di teras Pebble Bed dengan $\operatorname{Pr}=0.7, \varepsilon=0.39$

Dari Gambar 6, koefisien transfer panas meningkat (karena bilangan Nusselt meningkat) sesuai dengan peningkatan bilangan Reynolds, yang merupakan suatu fungsi laju alir massa. Ini merupakan peningkatan dalam laju alir massa pendingin yang menyebabkan transfer panas yang lebih tinggi akibat koefisien transfer panas yang lebih tinggi, yang mengarah pada teras yang lebih dingin.

Gambar 7 menunjukkan bilangan Nusselt sebagai suatu fungsi bilangan Reyolds untuk transfer panas konveksi partikel-ke-fluida untuk berbagai daerah teras pebble bed. Hasilnya menunjukkan bahwa transfer panas adalah lebih besar di bagian tengah teras dan lebih rendah di bagian dekat-dinding teras.

Kuantitas panas yang dapat dipindahkan oleh pendingin dari teras bergantung pada temperatur dan tekanan inlet pendingin. Besarnya koefisien transfer panas mempengaruhi proses transfer panas dan dipengaruhi oleh sejumlah parameter seperti geometri, laju alir dan temperatur pendingin, kondisi aliran dan jenis fluida.

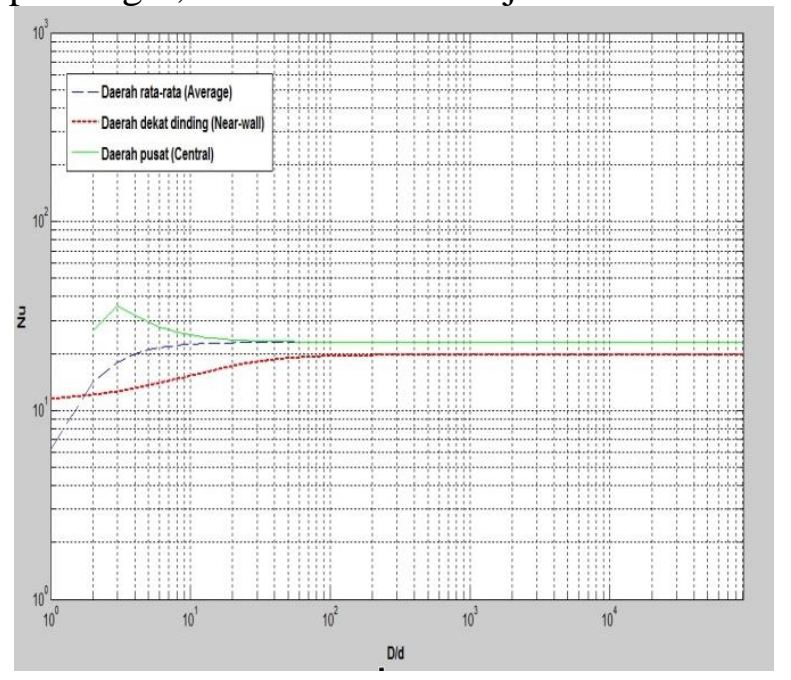

Gambar 7. Bilangan Nusselt sebagai Fungsi Bilangan Reynolds untukTransfer Panas Konveksi Partikel-ke-Fluida untuk Teras Pebble Bed
Gambar 8 menunjukkan kebergantungan temperatur pada koefisien transfer panas konveksi untuk berbagai laju alir massa. Dari hasil studi yang diperoleh, teramati bahwa koefisien transfer panas meningkat sesuai dengan peningkatan temperatur dan laju alir massa pendingin dan pada laju alir yang lebih tinggi (bilangan Reynolds yang lebih tinggi), perbedaan pada koefisien transfer panas menjadi lebih besar.

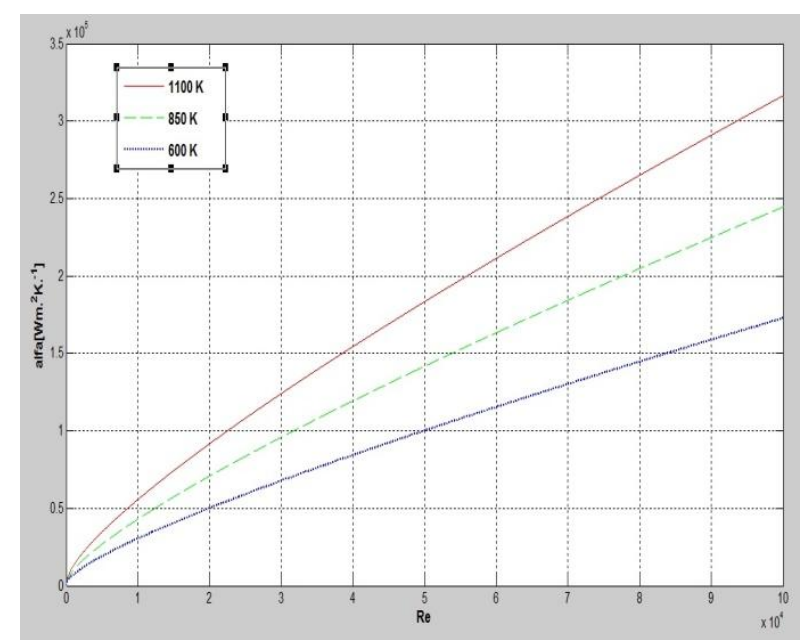

Gambar 8. Koefisien Transfer Panas

Konveksi $\alpha$ untuk Teras Pebble Bed sebagai Fungsi Bilangan Reynolds

\section{Konduktivitas Termal Efektif}

Konduktivitas termal efektif pebble bed yang dihitung dengan persamaan (15), (18), (19), dan (21) ditunjukkan pada Gambar 9. Seperti tampak pada Gambar 9, kebergantungan yang kuat konduktivitas termal efektif pebble bed pada temperatur tampak teramati.Perbandingan konduktivitas termal efektif di antara korelasi tersebut menunjukkan bahwa transfer panas yang dihasilkan dari radiasi interstitial void konduksi padatan adalah sangat signifikan, karena yang lainnya memiliki dampak yang sangat kecil pada konduktivitas termal efektif total.

Konduktivitas termal efektif pebble bed dipengaruhi oleh banyak parameter dengan tingkat yang berbeda. Parameter seperti konduktivitas termal pebble bahan bakar dan gas helium, tekanan gas, fraksipacking dan dosis radiasi neutron cepat memiliki dampak yang signifikan pada 
konduktivitas termal pebble bed. Parameter lainnya seperti ukuran pebble bed dan kekasaran permukaan memiliki dampak yang lebih kecil pada konduktivitas termal pebble bed.

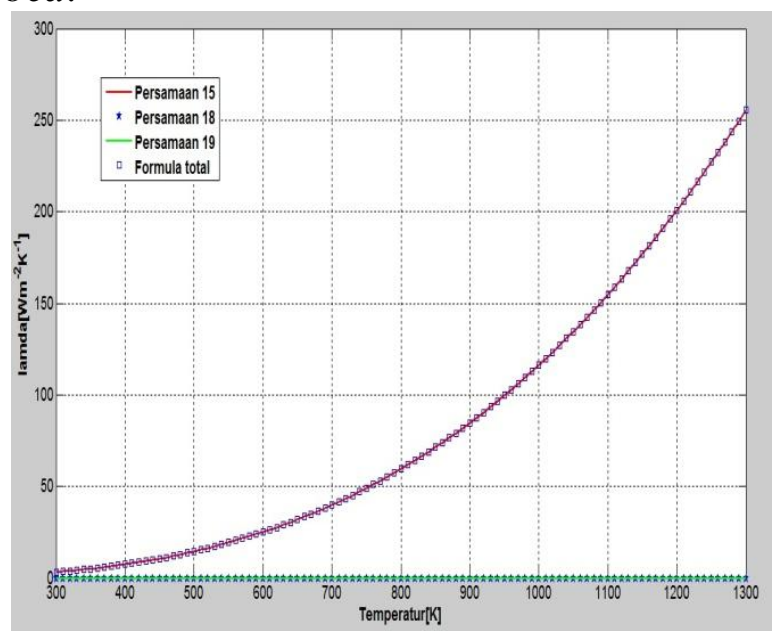

Gambar 9. Konduktivitas Termal Efektif Pebble Bed untuk Kondisi Helium

\section{KESIMPULAN}

Dari hasil studi telah diperolehsuatu model matematis dengan kemampuan untuk mensimulasikan aliran fluida dan perpindahan panas dalam teras reaktor modular pebble bed.Model ini berhasil diterapkan pada personal computer (PC) yang menggunakan program komputer Matlab r2008a Versi 7.1.Model ini dapat menjelaskan secara memadai fenomena aliran panas dan perpindahan panas serta kehilangan tekanan akibat friksi dalam PBMR tipe pebble bed.

Parameter koefisien penurunan tekanan dan penurunan tekanan dapat dikorelasikan pada seluruh kisaran bilangan Reynolds terkait. Simulasi yang dilakukan sangat sesuai dengan hasil eksperimen seperti yang dilaporkan pada literatur. Parameter konduktivitas termal efektif PBMR dari berbagai model yang dilakukan dengan korelasi antara hasil eksperimental telah diprediksi secara baik.

\section{PUSTAKA}

1. Lomonaco, G., W, Grassi and N. Cerullo, "The Influence of the Packing on the Fuel Temperature Hot Spots in a particle-Bed GCFR",
Hindawi Publishing Corporation Science and Technology of Nuclear Installations. Article ID:291453, 2009.

2. Du Toit. C.G., The numerical determination of the variation in the porosity of the pebble bed core. Proc. Top1 Mtg. High Temperature Reactor Technology (HTR-TM). April 22-24, 2002.

3. Achenbach, E., "Heat and fluid flow characteristics of packed Beds". Exp. Therm. Fluid Sci., 10: 17-27, 1995

4. Pieter, J.V. and N.M.Mark, "Integrated design approach of the pebble bed modular reactor using models". Nuclear Eng.Des. 237:1341-1353, 2007. 4

5. Achenbach, E., "Helium Cooled Systems, HTR-Pebble Bed Design", Pergamon Press Inc., New York. Pp: 381-405, 1981

6. KTA.S.,"Reactor core design of High Temperature Gas-Cooled Reactors. Nuclear Safety Standards Commision". KTA standars 3102.1.3102.2.3102.3, 1978, 1981, 1983.

7. IAEA TECDOC-1163, "Heat Transport and After Heat Removal for Gas Cooled Reactors Under Accident Conditions International Atomic Energ Agency",2000.

8. Breitbach. G. And H. Barthels., "The radiation heat transfer in the HTR core after failure of the afterheat removal system",. Nuclear Technol., 49:392-399, 1980

9. Bauer, R. And E.U. Schluender, "Effective radial thermal conductivity ofPackings in gas flow Part 2: Thermal conductivity of the packing fraction withoutGas flow". Inter. Chem. Eng., 18: 189-204,1978.

10. Yanhua. Z., S. Lei and D.Yujie.,"Thermohydraulic transient studies of the Chinese 200 MWE HTR-PM for loss of forced cooling accidents". Ann. Nucl.Energ., 36:742-751, 2009. 